\title{
The use of oral suspension and rationally prescribing alternatives may be supplemental to the implementation of clopidogrel new algorithm comprising CYP2CI 9 pharmacogenetics and drug interactions
}

\section{Meng Chen \\ Quan Zhou}

Department of Pharmacy, The Second Affiliated Hospital, School of Medicine, Zhejiang University, Hangzhou, Zhejiang Province, People's Republic of China
Correspondence: Quan Zhou

Department of Pharmacy, The Second Affiliated Hospital, School of Medicine,

Zhejiang University, 88 jiefang Road,

Hangzhou 310009, Zhejiang Province,

People's Republic of China

$\mathrm{Tel}+8657187784615$

Fax +86 57। 87022776

Email zhouquan142602@zju.edu.cn
This article was published in the following Dove Press journal:

Therapeutics and Clinical Risk Management

2 March 2016

Number of times this article has been viewed

\section{Dear editor}

We read with great interest the study by Saab et al, ${ }^{1}$ which shows that all patients who received combination therapy of clopidogrel and cytochrome P540 2C19 (CYP2C19) substrates require clopidogrel dose adjustment if they are not $C Y P 2 C 19 * 1 / * 1$ carriers and that therapeutic dose of $75 \mathrm{mg}$ clopidogrel should be tailored in patients with different genotypes (eg, lowered to $6 \mathrm{mg}$ or increased to $215 \mathrm{mg}$ ) for the sake of efficacy and safety. We especially appreciate the new clinical pharmacogenetic algorithm they developed to optimize clopidogrel-based treatment. However, we found two points worthy of discussion and would like to share our perspectives in the following paragraphs.

\section{Use of oral suspension}

The conventional maintenance dose of clopidogrel is $75 \mathrm{mg}$ once daily orally. There are two dosage forms and strengths for Plavix ${ }^{\circledR}$ (clopidogrel bisulfate, Bristol-Myers Squibb/ Sanofi Pharmaceuticals Partnership, Bridgewater, NJ, USA), that is, 75 and $300 \mathrm{mg}$ per tablet. ${ }^{2}$ So, a practical breaking problem is encountered, that is, how can clopidogrel at a special dose (eg, 6 or $215 \mathrm{mg}$ ) be administered to patients? Generally, a small piece (a quarter of a pill) is the bottom line in subdividing ("breaking") of an intact tablet because the tablet splitting process is annoying as well as being susceptible to inaccuracy of dosage ${ }^{3,4}$ Extemporaneously compounded suspensions of clopidogrel $(5 \mathrm{mg} / \mathrm{mL})$ in a 1:1 mixture of Ora-Plus and Ora-Sweet were stable for at least 60 days when stored in amber plastic bottles at room temperature and under refrigeration. ${ }^{5}$ Also, a $5 \mathrm{mg} / \mathrm{mL}$ clopidogrel oral suspension stored under refrigeration and at room temperature maintains chiral stability as the active S-enantiomer. ${ }^{6}$ A study by Zafar et $\mathrm{al}^{7}$ shows that a $300 \mathrm{mg}$ loading dose of clopidogrel given crushed via nasogastric tube provides faster absorption than an equal dose taken orally as whole tablets, but bioavailability was similar over the 24-hour period with both administration methods. Collectively, clopidogrel at a special dose (eg, 6 or $215 \mathrm{mg}$ ) may be administered in the form of oral extemporaneously compounded suspension. It is promising to develop a liquid pharmaceutical formulation of clopidogrel for the sake of convenience and dose accuracy. 


\section{Rationally selecting alternatives}

We observe that the kind of proton pump inhibitor (PPI) or P2Y12 inhibitor determines the risk level of CYP2C19mediated drug-drug interactions between classes of drugs. Clinicians should avoid prescribing omeprazole and esomeprazole for patients taking clopidogrel. The potential of proton pump inhibitors (PPIs) to attenuate the efficacy of clopidogrel could be minimized by use of pantoprazole, dexlansoprazole, or rabeprazole, rather than esomeprazole or omeprazole. ${ }^{8}$ Meanwhile, the P2Y12 inhibitors have different pharmacokinetic characteristics. The conversion of clopidogrel to its active metabolite requires two sequential oxidative steps. The first step leads to the formation of 2-oxo-clopidogrel, followed by conversion to the active metabolite. CYP2C19 contributes substantially to both oxidative steps and CYP3A4 contributes substantially to the second oxidative step. Prasugrel is also a prodrug that is activated by a two-step metabolism initiated by plasma esterases and further catalyzed by a single CYP-dependent step that primarily involves CYP3A and CYP2B6, and only partially CYP2C9 and CYP2C19. Ticagrelor undergoes extensive CYP3A4-mediated metabolism to produce an active metabolite; both the parent drug and the active metabolite can reversibly inhibit the P2Y12 receptor. PPIs use was associated with higher platelet reactivity with clopidogrel but not ticagrelor. ${ }^{9}$ There is no substantive evidence that PPIs attenuate the therapeutic effect of prasugrel or ticagrelor; therefore, prasugrel and ticagrelor may be alternatives that can escape the adverse drug-drug interactions induced by PPIs compared with clopidogrel..$^{8-11}$

We reported that incidence rate of CYP2C19 poor metabolizers in Chinese populations is far higher than that in Caucasians ( $25 \%$ versus $2 \%-5 \%$ ) and it is very necessary to perform genotyping of CYP2C19 prior to initiation of clopidogrel treatment in Chinese subjects. ${ }^{12}$ The new clinical algorithm comprising CYP2C19 pharmacogenetics and drug interactions developed by Saab et al is very practical and beneficial in optimizing clopidogrel treatment. ${ }^{1}$ Their study along with our perspectives may bring a more detailed guide in personalized antiplatelet therapy.

\section{Acknowledgment}

This work was supported by National Natural Science Foundation of China (81373488).

\section{Disclosure}

The authors report no conflicts of interest in this communication.

\section{References}

1. Saab YB, Zeenny R, Ramadan WH. Optimizing clopidogrel dose response: a new clinical algorithm comprising CYP2C19 pharmacogenetics and drug interactions. Ther Clin Risk Manag. 2015;11: $1421-1427$.

2. Plavix. [webpage on the Internet]. Available from: http://www.rxlist. com/plavix-drug/indications-dosage.htm. [Updated August 17, 2015.] Accessed December 9, 2015.

3. Rodenhuis N, de Smet PA, Barends DM. Patient experiences with the performance of tablet score lines needed for dosing. Pharm World Sci. 2003;25:173-176.

4. Stimpel M, Vetter H, Küffer B, Groth H, Greminger P, Vetter W. The scored tablet - a source of error in drug dosing? J Hypertens Suppl. 1985; 3:S97-S99.

5. Skillman KL, Caruthers RL, Johnson CE. Stability of an extemporaneously prepared clopidogrel oral suspension. Am J Health Syst Pharm. 2010;67:559-561.

6. Tynes CR, Livingston B, Patel H, Arnold JJ. Chiral stability of an extemporaneously prepared clopidogrel bisulfate oral suspension. J Pediatr Pharmacol Ther. 2014;19:25-29.

7. Zafar MU, Farkouh ME, Fuster V, Chesebro JH. Crushed clopidogrel administered via nasogastric tube has faster and greater absorption than oral whole tablets. $J$ Interv Cardiol. 2009;22:385-389.

8. Wang ZY, Chen M, Zhu LL, et al. Pharmacokinetic drug interactions with clopidogrel: updated review and risk management in combination therapy. Ther Clin Risk Manag. 2015;11:449-467.

9. Storey RF, Angiolillo DJ, Patil SB, et al. Inhibitory effects of ticagrelor compared with clopidogrel on platelet function in patients with acute coronary syndromes: the PLATO (PLATelet inhibition and patient Outcomes) PLATELET substudy. J Am Coll Cardiol. 2010; $56: 1456-1462$.

10. Thomas MR, Storey RF. Optimal management of antiplatelet therapy and proton pump inhibition following percutaneous coronary intervention. Curr Treat Options Cardiovasc Med. 2012;14:24-38.

11. Goodman SG, Clare R, Pieper KS, et al. Association of proton pump inhibitor use on cardiovascular outcomes with clopidogrel and ticagrelor: insights from the platelet inhibition and patient outcomes trial. Circulation. 2012;125:978-986.

12. Zhao XY, Xu HM, Zhou Q. Sampling times and genotyping concerns in bioequivalence evaluation of branded and generic formulations. Ther Clin Risk Manag. 2013;9:463-468.

Dove Medical Press encourages responsible, free and frank academic debate. The content of the Therapeutics and Clinical Risk Management 'letters to the editor' section does not necessarily represent the views of Dove Medical Press, its officers, agents, employees, related entities or the Therapeutics and Clinical Risk Management editors. While all reasonable steps have been taken to confirm the content of each letter, Dove Medical Press accepts no liability in respect of the content of any letter, nor is it responsible for the content and accuracy of any letter to the editor.

\section{Publish your work in this journal}

Therapeutics and Clinical Risk Management is an international, peerreviewed journal of clinical therapeutics and risk management, focusing on concise rapid reporting of clinical studies in all therapeutic areas, outcomes, safety, and programs for the effective, safe, and sustained use of medicines. This journal is indexed on PubMed Central, CAS,
EMBase, Scopus and the Elsevier Bibliographic databases. The manuscript management system is completely online and includes a very quick and fair peer-review system, which is all easy to use. Visit $\mathrm{http}: / /$ www.dovepress.com/testimonials.php to read real quotes from published authors. 